\title{
Pengaruh Model Pembelajaran Kooperatif Tipe Jigsaw I dan Motivasi Belajar Terhadap Hasil Belajar Pendidikan
} Kewarganegaraan

\author{
${ }^{*}$ I Md. Adi Jaya Wibawa1, I Md. Suarjana² \\ 1,2 Jurusan Pendidikan Guru Sekolah Dasar Fakultas Ilmu Pendidikan, Universitas Pendidikan Ganesha, Indonesia
}

\author{
A R T I C L E I N F O \\ Article history: \\ Received 01 December \\ 2018 \\ Received in revised form \\ 30 December 2018 \\ Accepted 15 January 2019 \\ Available online 25 \\ February 2019
}

\section{Kata Kunci:}

hasil belajar, jigsaw $I$,

motivasi belajar.

Keywords:

learning achievement, jigsaw I, learning

motivation.

\begin{abstract}
A B S T R A K
Kurangnya motivasi belajar Pendidikan Kewarganegaraan berpengaruh terhadap rendahnya hasil belajar Pendidikan Kewarganegaraan.Penelitian ini bertujuan untuk mengetahui perbedaan yang signifikan hasil belajar PKn, pengaruh interaksi antara model pembelajaran kooperatif Tipe Jigsaw I dengan motivasi belajar terhadap hasil belajar PKn, perbedaan hasil belajar PKn menggunakan model pembelajaran kooperatif tipe Jigsaw I dengan model pembelajaran konvensional, pada siswa yang memiliki motivasi belajar tinggi, mengetahui perbedaan hasil belajar PKn antara siswa dengan model pembelajaran kooperatif tipe Jigsaw I dan menggunakan model pembelajaran konvensional, pada siswa yang memiliki motivasi belajar rendah. Populasi dalam penelitian ini adalah seluruh siswa kelas V SD. Sampel diambil dengan teknik random sampling yang berjumlah 48 siswa, terdiri dari 2 kelas eksperimen dan dua kelas kontrol. Analisis hasil penelitian ini menggunakan Anava dua jalur. Perhitungan dengan
\end{abstract} uji t-Scheffe menunjukkan nilai Thitung antara A1B1 dan A2B1 sebesar 5,89, sedangkan $T_{\text {tabel }}$ pada taraf signifikansi $5 \%$ dengan $\mathrm{k}=4$ dan $\mathrm{dk}=44$ maka diperoleh $\mathrm{T}_{\text {tabel }}=3,79$. Hasil tersebut menunjukkan nilai Thitung lebih besar daripada Qtabel sehingga $\mathrm{H}_{0}$ ditolak dan $\mathrm{H}_{1}$ diterima. $\mathrm{Hal}$ itu berarti untuk kelompok siswa yang memiliki motivasi tinggi, terdapat perbedaan yang signifikan hasil belajar PKn antara siswa yang mendapat perlakuan model pembelajaran kooperatif tipe Jigsaw I dengan yang mendapat perlakuan pembelajaran konvensional.

\begin{abstract}
A B S T RAC T
This research aimed to investigate (1) the significant difference of Civics learning achievement between students who followed cooperative learning model type Jigsaw I and students who were treated with conventional learning, (2) the interaction effect between cooperative learning model type Jigsaw I and learning motivation on the Civics learning achievement, (3) the difference of Civics learning achievement between students who followed cooperative learning model type Jigsaw I and students who were treated with conventional learning on the students who have higher learning motivation. (4) the difference of Civics learning achievement between students who followed cooperative learning model type Jigsaw I and students who followed conventional learning on the students who have lower learning motivation. The analyze result showed that: (1) there is significant difference of Civics learning achievement between students who followed cooperative learning model type Jigsaw I and students who followed conventional learning; (2) there is significant interaction effect between the learning model and the learning motivation on students' Civics learning achievement, (3) on the students with high learning motivation, there is a difference of Civics learning achievement between students who followed cooperative learning model type Jigsaw I and students who followed conventional learning, (4) on the students with low learning motivation, there is a significant difference of Civics learning achievement between students who followed cooperative learning model type Jigsaw I and students who followed conventional learning. So, it can be concluded that cooperative learning model type Jigsaw I and learning motivation have effect on the Civics learning achievement of fifth grade students Cluster IX in Mengwi subdistrict.
\end{abstract}




\section{Pendahuluan}

Tujuan pendidikan di Indonesia diharapkan dapat mempersiapkan peserta didik menjadi warga negara yang memiliki komitmen kuat dan konsisten untuk mempertahankan Negara Kesatuan Republik Indonesia (NKRI). Komitmen yang kuat dan konsisten terhadap prinsip dan semangat kebangsaan dalam kehidupan bermasyarakat, berbangsa dan bernegara yang berdasarkan Pancasila dan UUD 1945, perlu ditingkatkan terus-menerus memberikan pemahaman yang mendalam tentang NKRI. Konstitusi Negara Republik Indonesia perlu ditanamkan kepada seluruh komponen bangsa Indonesia, khususnya generasi muda sebagai penerus bangsa(Susanto, 2013) . Seiring dengan perkembangan Ilmu pengetahuan dan teknologi, maka secara otomatis pola pikir masyarakat berkembang dalam setiap aspek. Hal ini sangat berpengaruh besar terutama dalam dunia pendidikan yang menuntut adanya inovasi baru yang dapat menimbulakan perubahan. Penyelenggaraan pendidikan di sekolah dasar, dimana guru memegang peranan utama danbertanggung jawab memberikan gagasan baru, baik terhadap siswa maupun masyarakat melalui proses kegiatan pembelajaran (Susanto, 2013).

Pendidikan kewarganegaraan adalah mata pelajaran yang digunakan sebagai tempat untuk mengembangkan dan melestarikan nilai moral yang berakar pada budaya bangsa indonesia. Nilai-nilai moral ini dirahapkan dapat diwujudkan dalam bantuk perilaku kehidupan siswa sehari-hari, baik sebagai individu maupun anggota masyarakat dan makhluk cipataan Tuhan Yang Maha Esa. Hal ini dapat membekali siswa dengan pengetahuan dan kemampuan dasar agar menjadi warga negara yang dapat berguna bagi bangsa dan negara. Menurut Azyumandi (dalam Susanto, 2013:226) "menyatakan bahwa pendidikan kewarganegaraan yang mengkaji dan membahas tentang pemerintah, konstitusi, lembagalembaga demokrasi, rule of law, HAM, hak dan kewajiban warga negara serta proses demokrasi". Sedangkan menurut Zamroni (dalam Susanto, 2013:226) menyatakan, pendidikan kewarganegaraan adalah pendidikan demokrasi yang bertujuan untuk mempersiapkan warga masyarakat berpikir kritis dan bertindak demokrasi. Pendidikan kewarganegaraan adalah pendidikan demokrasi yang bertujuan untuk mendidik generasi muda menjadi warga negara yang demokrasi dan partisipatif melalui sesuatu pendidikan yang diagonal.

Pendidikan kewarganegaraan adalah pendidikan yang memberikan pemahaman dasar untuk siswa maupun warga masyarakat agar bisa berpikir keritis dan bertindak demokrasi. Pendidikan kewarganegaraan ini diharapkan mampu membina dan mengembangkan peserta didik agar menjadi warga negara yang baik.Pendidikan kewarganegaraan di sekolah dasar memberikan pelajaran kepada siswa untuk memahami dan membiasakan dirinya dalam kehidupan di sekolah atau di luar sekolah, karena materi pendidikan kewarganegaraan menekankan pada pengalaman dan pembiasaan dalam kehidupan sehari-hari yang ditunjang oleh pengetahuan. Tujuan pembelajaran PKn ini adalah agar siswa dapat melaksanakan hak dan kewajiban secara santun, jujur, demokrasi serta ikslas dan bertanggung jawab (Susanto, 2013).Mengingat pentingnya pembelajaran PKn, guru sebagai peranan pendidik harus mampu mengemas pembelajaran menjadi menyenangkan dan juga bermakna bagi siswa. Salah satu cara yang dapat dilakukan yaitu dengan menerapkan model-model pembelajaran yang inovatif dalam proses kegiatan pembelajaran. Penggunaan model pembelajaran yang tepat mampu meningkatkan hasil dan partisipasi siswa dalam proses pembelajaran. Siswa akan menjadi lebih aktif dan termotivasi sehingga pembelajaran dapat berlangsung secara efektif yang akan berakibat pada peningkatan hasil belajar dan motivasi belajar siswa.

Atas berbagai pengalaman yang terjadi di lapangan bahwa penyebab hambatan belajar pada siswa sangat kompleks sehingga permasalahan yang timbul juga kompleks seperti: model atau metode pembelajaran, masalah motivasi belajar siswa, bagaimana terhadap kelompok siswa yang memiliki kemampuan dan motivasi belajar rendah serta bagaimana terhadap kelompok yang mempunyai kemampuan dan motivasi belajar tinggi dan lain-lain, yang pada akhirnya sebagai tolak ukur adalah hasil belajar siswa dalam proses pembelajaran. Namun pada kenyataan yang ada di SD Gugus IX Kecamatan Mengwi tidak sesuai dengan apa yang diharapkan. Banyak siswa yang mengalami kesulitan dalam memahami materi PKn karena sebagian besar cakupan materinya bersifat hafalan. Siswa juga menganggap bahwa pembelajaran PKn sangat menjenuhkan sehingga siswa cendrung melakukan kegiatan lain yang lebih menarik dibandingkan dengan mendengarkan penjelasan guru di depan kelas. Hal ini tentunya akan membuat mata pelajaran PKn seolah-olah menjadi beban di mata siswa. Kenyataan ini yang mengakibatkan rendahnya motivasi belajar siswa terhadap mata pelajaran PKn. Berdasarkan hasil wawancara awal yang dilakukan 6 orang guru kelas V di SD Gugus IX Kecamatan Mengwi pada tanggal 1415 Desember 2017 diketahui bahwa: a) siswa kurang berpartisipasi aktif saat proses pembelajaran berlangsung, b) guru tidak menggunakan model pembelajaran yang bervariasi, c) kurang adanya interkasi 
siswa dengan guru saat pembelajaran sehingga masih pasif, dan d) hasil belajar yang diperoleh siswa masih di bawah KKM khususnya pada mata pelajaran PKn. Hasil wawancara tersebut didukung oleh hasil observasi mengenai pelaksanaan pembelajaran di kelas.

Berdasarkan hasil obsevasi pengamatan proses pembelajaran PKn yang dilakukan pada guru mata pelajaran PKn kelas V SD Gugus IX Kecamatan Mengwi pada tanggal 8-9 Januari 2018 diketahui bahwa dari 6 orang guru yang diobsevasi, sebanyak 5 guru tidak menggunakan metode atau model pembelajaran yang bervariasi, sehingga mengakibatkan proses pembelajaran menjadi kurang menarik dan membosankan. Hasil obsevasi juga menunjukkan siswa saat proses pembelajaran kurang berpartisipasi serta kurang adanya interaksi antar guru dengan siswa. Hal ini menjadikan proses pembelajaran yang dilakukan oleh guru bersifat pasif. Pelaksanaan pembelajaran yang diterapkan oleh guru lebih banyak menggunakan metode ceramah, menyebabkan terjadinya komunikasi satu arah dari guru terhdap siswa, sehingga siswa kurang aktif, mudah bosan, meteri pelajaran kurang dipahami oleh siswa dan hanya menerima informasi.Untuk mengatasi permasalahan tersebut, diperlukan adanya perubahan dalam proses pembelajaran agar lebih inovatif, kreatif, dan menarik perhatian siswa. Salah satu model pembelajaran yang dapat meningkatkan hasil belajar siswa adalah model pembelajaran kooperatif tipe Jigsaw I.

Model pembelajaran Kooperatif tipe Jigsaw I adalah sebuah model belajar kooperatif yang menitikberatkan pada kerja kelompok siswa dalam bentuk kelompok kecil. Menurut Lie (1999:73), bahwa "pembelajaran kooperatif model Jigsaw I ini merupakan model belajar kooperatif dengan cara siswa belajar dalam kelompok kecil yang terdiri dari empat sampai enam orang secara heterogen dan siswa bekerja sma saling ketergantungan positif dan bertanggung jawab secara mandiri". Berdasarkan pemaparan model pembelajaran Jigsaw I tersebut, maka dapat memacu siswa dalam belajar sehingga hasil belajar siswa akan menjadi maksimal.

Jigsaw merupakan pembelajaran kooperatif dengan pengelompokkan siswa yang heterogen. Selain itu, dalam proses pembelajarannya seluruh siswa yang terlibat memiliki tanggung jawab tersendiri yang akan diterimanya berupa lembar ahli yang menjadi fokus masing-masing anggota kelompok (Djudin, 2016). Pembelajaran kooperatif tipe jigsaw diartikan juga pembelajaran yang dalam aplikasi pembelajarannya dibentuk beberapa kelompok kecil dalam setiap satu kelompok ada satu yang akan bertanggung jawab untuk menguasai pokok bahan materi belajar dan satu orang tersebut yang harus bertanggung jawab untuk membelajarkan kepada kelompok lain dan kelompoknya(Suprihatin, 2017).

Penggunaan model pembelajaran, juga secara khusus dilihat tentang faktor motivasi belajar. "Motivasi belajar adalah dorongan internal dan eksternal pada siswa-siswa yang sedang belajar untuk mengadakan prubahan tingkah laku, pada umumnya dengan beberapa indikator atau unsur yang mendukung"(B.Uno, 2016:23). Setiap individu memiliki kemampuan yang berbeda-beda, begitu juga dalam belajar antara satu dengan yang lainya pasti berbeda. Hal ini peserta didik dalam kegiatan pembelajara memperoleh hasil yang lebih maksimal terhadap penugasan kompetensi dengan indikator yang ditentukan. Untuk mencapai itu diperlukan motivasi belajar yang tinggi dalam belajar sehingga tujuan belajar tercapai.Joyce dan Weil (dalam Rusman, 2010), model pembelajaran disusun berdasarkan berbagai prinsip-prinsip pembelajaran, teori-teori psikologis, sosiologis, analisis sistem atau teori-teori lain yang mendukung. Model pembelajaran kooperatif sendiri disusun berdasarkan prinsip/faham konstruktivisme. Joyce (dalam Suprijono, 2009) menyatakan bahwa fungsi model adalah each model guides us as we design instruction to help students achieve various objectives. Melalui model pembelajaran guru dapat membantu siswa mendapatkan informasi, ide, keterampilan, cara berpikir, dan mengekspresikan ide (Rosyindah, 2016).

Model pembelajaran kooperatif tipe Jigsaw merupakan model pembelajaran kooperatif, dengan siswa belajar dalam kelompok kecil yang terdiri dari 4-6 orang secara heterogen dan bekerjasama saling ketergantungan yang positif dan bertanggung jawab atas ketuntasan bagian materi pelajaran yang harus dipelajari dan menyampaikan materi tersebut kepada anggota kelompok yang lain (Suparman, 2014).Menurut Maznum (2009:3) model tipe jigsaw memiliki beberapa kelebihan diantaranya memacu siswa berfikir kritis, memacu siswa untuk membuat kata-kata yang tepat agar dapat menjelaskan kepada teman lain. Ini akan mengacu siswa mengembangkan kemampuan verbal dan sosialnya dan diskusi yang terjadi tidak didominasi oleh siswa-siswa tertentu, tapi semua siswa dituntut untuk menjadi aktif (Ismiyatun, 2014).

Berdasarkan uraian tersebut, maka peneliti tertarik untuk mengkaji lebih jauh mengenai pengaruh model pembelajaran Kooperatif Tipe Jigsaw I dan motivasi belajar terhadap hasil belajar PKn siswa melalui penelitian eksperimen yang berjudul "Pengaruh Model Pmebelajaran Kooperatif Tipe Jigsaw I dan Motivasi Belajar Terhadap Hasil Belajar PKn Siswa Kelas V SD Gugus IX Kecamatan Mengwi Tahun Pelajaran 2017/2018". 


\section{Metode}

Rancangan penelitian yang digunakan adalah post-test only controlgroup design dengan rancangan faktorial 2x2. Desain ini dapat dilihat pada Tabel 1.

Tabel 1. Post-Test Only Control Group Design

\begin{tabular}{llll}
\hline Kelas & Treatment & Post-test & \\
\hline $\mathrm{E}$ & $\mathrm{X}_{1}$ & $\mathrm{O}_{1}$ & \\
$\mathrm{~K}$ & $\mathrm{X}_{2}$ & $\mathrm{O}_{2}$ & \\
\hline & & & (Dantes,2017)
\end{tabular}

Populasi dalam penelitian ini adalah siswa kelas V SD Gugus VI Kecamatan Mengwi tahun pelajaran 2017/2018. Sekolah sampel adalah SD No. 4 Gulingan, SD No. 2 Gulingan, SD No. 3 Gulingan dan SD No. 6 Gulinga yang diambil dengan teknik random sampling. Sampel penelitian berjumlah 48 siswa yang terdiri dari 2 kelas eksperimen dan dua kelas kontrol. Analisis hasil penelitian ini menggunakan Anava dua jalur.

Pada penelitian ini terdapat tiga variabel yakni variabel bebas yaitu model pembelajaran Jigsaw I, variabel moderator yaitu motivasi belajar, dan variabel terikat yaitu hasil belajar PKn. Data yang perlu dikumpulkan dalam penelitian ini adalah data hasil belajar PKn siswa dan data motivasi belajar siswa. Data mengenai hasil belajar PKn dan motivasi belajar siswa diperoleh melalui metode tes. Tes hasil belajar PKn siswa berupa tes objektif (pilihan ganda) dengan jumlah soal 30 soal dan tes motivasi belajar siswa berupa tes kuesioner dengan jumlah 30 butir.

Data dianalisis menggunakan statistik deskriptif dan statistik inferensial. Statistik deskriptif digunakan untuk mendeskripsikan data yang meliputi mean, median, modus, varians, dan standar deviasi. Statistik inferensial digunakan untuk menguji hipotesis meliputi pengaruh model pembelajaran scramble dan konvensional terhadap hasil belajar PKn, dan pengaruh interaksi antara model pembelajaran dan motivasi belajar terhadap hasil belajar PKn siswa. Analisis data menggunakan uji ANAVA dua jalur (Dantes, 2012). Apabila uji anava dua jalur menunjukkan $\mathrm{H}_{1}$ diterima pada hipotesis ke-2 yakni terdapat pengaruh interaksi antara Jigsaw I dengan motivasi belajar terhadap hasil belajar PKn, maka perlu diadakan uji lanjut (post hoc) untuk mengetahui kelompok mana yang unggul dengan menggunakan uji tScheffe. Uji t-Scheffe digunakan untuk uji lanjut ANAVA apabila banyak responden atau banyak anggota pada tiap kelompok atau sel sama. Hasil uji t-Scheffe ini menjawab hipotesis 3 dan 4(Koyan, 2012). Adapun rumus uji t-Scheffey yaitu sebagai berikut.

$$
\mathrm{t}=\frac{\overline{\mathrm{X}}_{A_{1} B_{1}-\overline{\mathrm{X}}_{A_{2} B_{1}}}}{\sqrt{\frac{2 . \mathrm{RJKdal}}{\mathrm{n}}}} \quad \text { Keterangan: }
$$

Keterangan:

$$
\begin{aligned}
\overline{\mathrm{X}}_{A_{1} B_{1}=} & \text { rata-rata pada kelompok siswa yang memiliki motivasi belajar tinggi dengan } \\
& \text { menggunakan model pembelajaran Jigsaw } I \\
\overline{\mathrm{X}}_{A_{2} B_{1}=} & \text { rata-rata pada kelompok siswa yang memiliki motivasi belajar tinggi dengan } \\
& \text { menggunakan model pembelajaran konvensional } \\
\mathrm{RJKdal}= & \text { rata-ratajumlah kuadrat dalam } \\
\mathrm{n} & =\text { jumlah sampel }
\end{aligned}
$$

Kriteria pengujian untuk hipotesis 3 dan 4: jika thitung $>$ tabel pada taraf signifikansi $5 \%(\alpha=0,05)$, maka hipotesis nol $\left(\mathrm{H}_{0}\right)$ ditolak dan hipotesis alternatif $\left(\mathrm{H}_{1}\right)$ diterima

\section{Hasil dan Pembahasan}

Pada Data dalam penelitian ini dikelompokkan menjadi enam kelompok data, yakni : (1) skor hasil belajar PKn siswa mendapat perlakuan model pembelajaran kooperatif tipe Jigsaw I (A1), (2) skor hasil belajar PKn siswa yang tidak mendapat perlakuan model pembelajaran kooperatif tipe Jigsaw I (A2), (3) skor hasil belajar PKn yang mendapat perlakuan model pembelajaran kooperatif tipe Jigsaw I yang memiliki motivasi tinggi (A1B1), (4) skor hasil belajar PKn sisw yang mendapatkan model pembelajaran kooperatif tipe Jigsaw I yang memiliki motivasi rendah (A1B2), (5) skor hasil belajar PKn yang mendapat 
perlakuan pembelajaran konvensional yang memiliki motivasi belajar tinggi (A2B1), dan (6) skor hasil belajar PKn siswa yang mendapat perlakuan pembelajaran konvensional yang memiliki motivasi belajar rendah (A2B2).Maka deskripsi data yang berkaitan dengan mean, median, modus, varians dan standar deviasi untuk semua kelompok data di atas dapat dilihat pada Tabel 02 di bawah ini.

Tabel 2. Rekapitulasi Hasil Perhitungan Skor Hasil Belajar PKn

\begin{tabular}{lllllll}
\hline Deskripsi data & A1 & A2 & A1B1 & A1B2 & A2B1 & A2B2 \\
\hline Mean & 23,37 & 17,83 & 26,16 & 20 & 19,2 & 17,16 \\
Median & 24,5 & 17,75 & 26,5 & 18,50 & 19,16 & 17 \\
Modus & 25,48 & 17,10 & 27,5 & 18,49 & 19,1 & 16,5 \\
Varians & 22,02 & 8,49 & 3,72 & 13,90 & 6,20 & 899 \\
Standar Deviasi & 4,47 & 2,91 & \multirow{2}{*}{, 92} & 3,72 & 2,48 & 2,99 \\
Kategori & Sangat & \multirow{2}{*}{ Baik } & Sangat Baik & Sangat & Sangat & Baik \\
& Baik & & & & & \\
\hline
\end{tabular}

Dari Skor hasil belajar PKn siswa yang mendapat perlakuan model pembelajaran Jigsaw I, dapat dideskripsikan mean (M), median (Md), modus (Mo), varians, dan standar deviasi (s), yaitu: mean (M) = 23,37 median $(\mathrm{Md})=24,5$ modus $(\mathrm{Mo})=25,48$, varians $\left(\mathrm{s}^{2}\right)=22,02$ dan standar deviasi $(\mathrm{s})=4,47$. Dapat diketahui bahwa modus lebih besar dari median dan median lebih besar dari mean (Mo $>M d>M$ ). Dengan demikian, kurva yang terbentuk adalah kurva juling negatif yang berarti sebagian besar skor cenderung tinggi. Skor rata-rata (M) jika dikonversikan dengan kriteria acuan, nilai rata-rata termasuk kategori sangat baik.Sementara itu, skor hasil belajar PKn siswa yang mendapat perlakuan pembelajaran konvensional, dapat dideskripsikan mean (M), median (Md), modus (Mo), varians, dan standar deviasi (s), yaitu: mean $(\mathrm{M})=17,83$, median $(\mathrm{Md})=17,75$, modus $(\mathrm{Mo})=17,10$, varians $\left(\mathrm{s}^{2}\right)=8,49$, dan standar deviasi (s) = 2,91. Dapat diketahui bahwa modus lebih kecil dari median dan median lebih kecil dari mean $(\mathrm{Mo}<\mathrm{Md}<\mathrm{M})$. Dengan demikian, kurva yang terbentuk adalah kurva juling positif yang berarti sebagian besar skor cenderung rendah. Skor rata-rata (M) jika dikonversikan dengan kriteria acuan, nilai rata-rata termasuk kategori baik.

Skor hasil belajar PKn kelompok eksperimen dan memiliki motivasi belajar tinggi, dapat dideskripsikan mean (M), median (Md), modus (Mo), varians, dan standar deviasi (s), yaitu: mean (M) = 26,16 median $(\mathrm{Md})=26,5$, modus $(\mathrm{Mo})=27,5$, varians $\left(\mathrm{s}^{2}\right)=3,72$, dan standar deviasi $(\mathrm{s})=1,92$. Dapat diketahui bahwa modus lebih besar dari median dan median lebih besar dari mean (Mo $>M d>M$ ). Dengan demikian, kurva yang terbentuk adalah kurva juling negatif yang berarti sebagian besar skor cenderung tinggi. Apabila skor rata-rata (M) dikonversikan dengan kriteria acuan, nilai rata-rata termasuk kategori sangat baik.Sedangkan skor hasil belajar PKn siswa yang mendapat perlakuan pembelajaran kooperatif tipe Jigsaw I yang memiliki motivasi belajar rendah dapat dideskripsikan mean (M), median (Md), modus (Mo), varians, dan standar deviasi $(\mathrm{s})$, yaitu: mean $(\mathrm{M})=20$, median $(\mathrm{Md})=18,5$, modus $(\mathrm{Mo})=18,49$, varians $\left(s^{2}\right)=13,90$, dan standar deviasi $(s)=3,72$. Dapat diketahui bahwa modus lebih kecil dari median dan median lebih kecil dari mean $(\mathrm{Mo}<\mathrm{Md}<\mathrm{M})$. Dengan demikian, kurva di atas adalah kurva juling positif yang berarti sebagian besar skor cenderung rendah. Apabila skor rata-rata (M) dikonversikan dengan kriteria acuan, nilai rata-rata termasuk kategori sangat baik.

Pada skor hasil belajar PKn siswa yang mendapatkan perlakuan pembelajaran konvensional yang memiliki motivasi belajar tinggi dapat dideskripsikan mean (M), median (Md), modus (Mo), varians, dan standar deviasi (s), yaitu: mean $(M)=19,2$, median $(M d)=19,16$, modus $(M o)=19,1$, varians $\left(s^{2}\right)=6,20$, dan standar deviasi $(s)=2,48$. Dapat diketahui bahwa modus lebih kecil dari median dan median lebih kecil dari mean $(\mathrm{Mo}<\mathrm{Md}<\mathrm{M})$. Dengan demikian, kurva yang terbentuk adalah kurva juling positif yang berarti sebagian besar skor cenderung tinggi. Apabila skor rata-rata (M) jika dikonversikan dengan kriteria acuan, nilai rata-rata termasuk kategori sangat baik.Sedangkan hasil belajar PKn siswa yang mendapat perlakuan pembelajaran konvensional yang memiliki motivasi belajar rendah dapat dideskripsikan mean (M), median (Md), modus (Mo), varians, dan standar deviasi (s), yaitu: mean $(\mathrm{M})=$ 17,16 , median $(\mathrm{Md})=17$, modus $(\mathrm{Mo})=16,5$, varians $\left(\mathrm{s}^{2}\right)=8,99$, dan standar deviasi $(\mathrm{s})=2,99$.. Dapat diketahui bahwa modus lebih kecil dari median dan median lebih kecil dari mean $(\mathrm{Mo}<\mathrm{Md}<\mathrm{M})$. Dengan demikian, kurva yang terbentuk adalah kurva juling positif yang berarti sebagian besar skor cenderung tinggi. Apabila skor rata-rata (M) dikonversikan dengan kriteria acuan, nilai rata-rata termasuk kategori baik.

Setelah mengetahui hasil uji deskriptif kemudian dilakukan uji hipotesis. Namun sebelum itu, perlu dilakukan uji prasyarat terhadap sebaran data yang meliputi uji normalitas dengan menggunkan teknik 
Lilliefors dan uji homogenitas dengan uji Bartlet terhadap skor hasil belajar PKn. Berdasarkan hasil uji normalitas dan homogenitas didapatkan bahwa data hasil belajar PKn siswa pada keenam kelompok adalah normal dan homogen.Hasil pengujian hipotesis dapat dilihat pada rangkuman Anava dua jalur berikut ini.

Tabel 3. Ringkasan Anava Dua Jalur

\begin{tabular}{lllllll}
\hline Sumber Varian & JK & Dk & RJK & F & F tabel & Keterangan \\
\hline A & 234,12 & 1 & 234,12 & 28,55 & 4,08 & Signifikan \\
B & 310,09 & 1 & 310,09 & 37,81 & 4,08 & Signifikan \\
AB & 60,07 & 1 & 60,07 & 7,40 & 4,08 & Signifikan \\
Dalam & 361,01 & 44 & 8,20 & & & \\
Total & 965,92 & 47 & & & & \\
\hline
\end{tabular}

Uji hipotesis pertama diperoleh $\mathrm{F}_{\mathrm{A}}=28,55$ sedangkan $\mathrm{F}_{\text {tabel }}$ dengan $\mathrm{db}_{\text {pembilang }}=1$ dan $\mathrm{db}_{\text {penyebut }}=44$ untuk taraf signifikansi $5 \%=4,08$. Ini berarti, nilai $F_{A}$ lebih besar dari pada Ftabel $\left(F_{A}=28,55>F_{\text {tabel }}=\right.$ 4,08). Oleh karena itu, $\mathrm{H}_{0}$ ditolak dan $\mathrm{H}_{1}$ diterima. Ini berarti bahwa terdapat perbedaan hasil belajar $\mathrm{PKn}$ antara siswa yang mendapat perlakuan pembelajaran model pembelajaran kooperatif tipe Jigsaw I dengan siswa yang mendapat pembelajaran konvensional.Selanjutnyadiperoleh $F_{A B}=7,20$ pada pengujian hipotesis kedua, sedangkan $\mathrm{F}_{\text {tabel }}$ dengan $\mathrm{db}_{\text {pembilang }}=1$ dan $\mathrm{db}_{\text {penyebut }}=44$ untuk taraf signifikansi $5 \%=$ 4,08. Ini berarti, nilai $F_{A B}$ lebih besar dari pada $F_{\text {tabel }}\left(F_{A B}=7,20>F_{\text {tabel }}=4,08\right)$. Oleh karena itu, $H_{0}$ ditolak dan $\mathrm{H}_{1}$ diterima. Ini berarti bahwa terdapat perbedaan hasil belajar PKn siswa yang memiliki motivasi belajar tinggi dengan siswa yang memiliki motivasi belajar rendah.

Berdasarkan hasil di atas menunjukkan bahwa pada siswa yang memiliki motivasi tinggi, hasil belajar PKn kelompok siswa yang mendapat perlakuan model pembelajaran Jigsaw I lebih baik daripada kelompok siswa yang mendapat perlakuan pembelajaran konvensional. Sedangkan pada siswa yang memiliki motivasi belajar rendah, hasil belajar PKn kelompok siswa yang mendapat perlakuan model pembelajaran Jigsaw I lebih baik daripada kelompok siswa yang mendapat perlakuan pembelajaran konvensional. Pada uji hipotesis kedua menunjukkan adanya interaksi sehingga dilanjutkan dengan uji lanjut untuk mengetahui kelompok mana yang lebih unggul. Uji hipotesis ketiga menunjukan hasil perhitungan dengan uji t-scheffe menunjukkan nilai $\mathrm{T}_{\text {hitung }}$ antara A1B1 dan A2B1 sebesar 5,89, sedangkan $\mathrm{T}_{\text {tabel }}$ pada taraf signifikansi $5 \%$ dengan $\mathrm{k}=4$ dan $\mathrm{dk}=44$ maka diperoleh $\mathrm{T}_{\text {tabel }}=3,79$. Hasil tersebut menunjukkan nilai $\mathrm{T}_{\text {hitung }}$ lebih besar daripada $\mathrm{T}_{\text {tabel }}$ sehingga $\mathrm{H}_{0}$ ditolak dan $\mathrm{H}_{1}$ diterima. Hal itu berarti untuk kelompok siswa yang memiliki motivasi beljar tinggi, terdapat perbedaan yang signifikan pada hasil belajar PKn antara siswa yang mendapat perlakuan model pembelajaran kooperatif tipe Jigsaw I dengan siswa yang mendapat pembelajaran konvensional.

Apabila dilihat dari perbandingan rata-rata antara kelompok A1B1 dan A2B1, kelompok A1B1 memiliki rata-rata skor hasil belajar matematika lebih tinggi dibandingkan dengan kelompok A2B1. Ini menunjukkan bahwa kelompok siswa yang dibelajarkan dengan model pembelajaran scramble lebih unggul dibandingkan dengan kelompok siswa yang dibelajarkan dengan model pembelajaran konvensional, pada siswa yang memiliki kemampuan numerik tinggi. Uji hipotesis ketiga dengan uji tScheffe menunjukkan nilai $\mathrm{T}_{\text {hitung }}$ antara A1B2 dan A2B2 sebesar 5,46, sedangkan $\mathrm{T}_{\text {tabel }}$ pada taraf signifikansi $5 \%$ dengan $\mathrm{k}=4$ dan $\mathrm{dk}=44$ maka diperoleh $\mathrm{T}_{\text {tabel }}=3,79$. Hasil tersebut menunjukkan nilai Thitung lebih besar daripada $\mathrm{T}_{\text {tabel }}$ sehingga $\mathrm{H}_{0}$ ditolak dan $\mathrm{H}_{1}$ diterima. Hal itu berarti untuk kelompok siswa yang memiliki motivasi belajar rendah, terdapat perbedaan yang signifikan pada hasil belajar PKn antara kelompok siswa yang mendapat perlakuan model pembelajaran kooperatif tipe Jigsaw I dengan kelompok siswa yang mendapat perlakuan pembelajaran konvensional.

Apabila dilihat dari perbandingan rata-rata antara kelompok A1B2 dan A2B2, kelompok A1B2 tetap memiliki rata-rata skor hasil belajar PKn lebih tinggi dibandingkan dengan kelompok A2B2. Hal ini membuktikan bahwa penerapan model pembelajaran kooperati tipe Jigsaw I lebih baik dibandingkan dengan penerapan pembelajaran konvensional untuk mengembangkan hasil belajar PKn siswa, pada siswa yang memiliki motivasi belajar rendah.

Pencapaian hasil belajar siswa dipengaruhi oleh proses pembelajaran yang dilalui oleh siswa di sekolah. Hasil belajar merupakan hasil yang dicapai dalam proses pembelajaran dalam jangka waktu tertentu yang mencakup sejumlah pengetahuan, keterampilan dan perilaku yang ditanyakan dengan angka atau nilai dan adanya perubahan tingkah laku. Hasil belajar mempunyai peranan yang sangat penting dalam pendidikan, bahkan kualitas pendidikan tercermin dari hasil belajar siswa. Oleh karena itu, hasil belajar penekanannya terletak pada hasil yang dicapai dari suatu kegiatan atau aktivitas. 
Hal diatas dapat disebabkan oleh beberapa faktor, yakni kelompok siswa yang mendapatkan perlakuan model pembelajaran kooperatif tipe Jigsaw I dan kelompok siswa yang mendapat perlakuan pembelajaran konvensional memiliki perbedaan hasil belajar PKn yang signifikan dikarenkan pembelajaran yang dilaksanakn mengcu pada perbedaan langkah-langkah dalam pembelajarannya. Dalam model pembelajaran Jigsaw I siswalah yang lebih aktif dalam pembelajaran dibandingkan dengan kelompok siswa yang mengikuti pembelajaran konvensional, yakni guru lebih banyak menguasai materi pembelajaran. Hal ini justru menyebabkan perbedaan hasil belajar PKn yang diperoleh antara kelompok siswa yang mendapat perlakuan model kooperatif tipe Jigsaw I dan kelompok siswa yang mendapat perlakuan pembelajaran konvensioanl. Hal ini sejalan dengan pendapat Rusman (2016) pembelajaran kooperatif jigsaw I ini siswa memiliki banyak kesempatan untuk mengemukakan pendapat dalam mencari informasi yang didapat dan dapat meningkatkan keterampilan berkomunikasi, anggota kelompok bertanggung jawab terhadap keberhasilan kelompok nya dan ketuntasan bagian materi yang dipelajari dan dapat menyampaikan informasinya kepada kelompok lain. Sudah jelas dikatakan bahwa model Jigsaw I lebih menitikberatkan pada keterlibatkan siswa secara aktif dalam pembelajaran. Sedangkan pembelajaran konevnsional masih menitikberatkan pada aktivitas guru yang solah olah menguasi pembelajaran. Trianto (2010) yang menyatakan bahwa pembelajaran konvensional mendorong siswa untuk menghafal materi yang disampaikan, sehingga pembelajaran lebih terlihat sebagai proses meniru, yaitu siiswa dituntut untuk mengungkapkan kembali pengetahuan yang didapat dari guru, bukan mengungkapkan kembali pengetahuan yang didapat dari guru, bukan berdasarkan pengalaman belajar yang dialaminya.

Sejalan dengan pendapat di atas, Rusman (2016) menyatakan kelebihan sebagai berikut: (1) dapat mengembangkan kreativitas antara pribadi siswa dianatara siswa yang memiliki kemampuan belajar yang berbeda, (2) adanya hubungan antara guru dan siswa terjalian sangat baik, sehingga suasana belajar menjadi harmonis, (3) meningkatkan motivasi belajar siswa agar bekerja lebih aktif dan kreatif, (4) mampu memadukan berbagai pendekatan belajar, sehingga siswa bisa memahami materi lebih mendalam.Penelitian ini sejalan dengan penelitian yang di lakukan oleh Adi pada tahun 2015 yang berjudul "Pengaruh Model Pembelajaran Kooperatif Tipe Jigsaw I dengan Berbantuan Media Konkret terhadap Hasil Belajar IPA Siswa Kelas V Semester II di SD Gugus XIV, Kecamatan Buleleng". Hasil penelitian yang telah dilakukan menyatakan bahwa, terdapat perbedaan yang signifikan hasil belajar IPA antara kelompok siswa yang mengikuti pembelajaran dengan model pembelajaran kooperatif tipe jigsaw I dengan berbantuan media konkret dengan kelompok siswa yang mengikuti pembelajaran dengan model pembelajaran kooperatif. Adanya perbedaan yang signifikan menunjukkan bahwa model pembelajaran kooperatif tipe jigsaw I dengan berbantuan media konkret berpengaruh positif terhadap hasil belajar IPA siswa dibandingkan dengan model pembelajaran kooperatif.

Siswa yang memiliki motivasi belajar tinggi akan lebih mudah menyesuaikan dan menghubungkan apa yang telah dipahaminya dengan apa yang dibelajarkan oleh guru sebagai sebuah pengetahuan baru dibandingkan dengan siswa yang memiliki motivasi belajar rendah. Selanjutnya siswa yang memiliki motivasi belajar tinggi cepat dan uleht dalam menanggapi dan merespon pertanyaan yang diberikan oleh guru. Selain itu siswa yang memiliki motivasi belajar tinggi akan lebih cepat melakukan pemahaman konsep dan generalisasi secara utuh melalui proses akomodasi sosial akademis.Selanjutnya, siswa yang memiliki motivasi belajar rendah akan lebih malas dan lamban melakukan pemahaman konsep. Sejalan dengan itu, Kamal (dalam Puspitasari, 2013), "motivasi belajar adalah keseluruhan daya penggerak, pemberi rangsang dan penggerak tingkah laku baik dari dalam maupun dari luar siswa dengan menciptakan serangkaian usaha untuk memberikan arahan pada kegiatan belajar, sehingga peserta didik mampu mencapai tujuan belajar yang baik.

Penelitian ini sejalan dengan penelitian yang dilakukan oleh Murda (2013) yang menunjukan bahwa, motivasi belajar memberikan sumbangan yang cukup signifikan terhadap hasil belajar. Kemudiann data lain yang mendukung ialah penelitian yang dilakukan oleh Hyani (2013) yang menemukan bahwa, terdapat kontribusi yang signifikan dari motivasi belajar terhadap hasil belajar siswa Oleh karena itu, dapat dikatakan bahwa motivasi belajar yang dimiliki siswa akan menghasilkan perolehan hasil belajar yang maksimal apabila dikombinasikan dengan pendekatan pembelajaran yang tepat.

Hasil tersebut membuktikan bahwa, hasil belajar PKn tidak hanya dipengaruhi oleh jenis model pembelajaran yang digunakan dalam pembelajaran, tetapi dipengarui juga oleh faktor lain seperti motivasi belajar yang dimiliki oleh siswa. Sehingga di dalam proses pembelajaran seorang guru harus mampu melihat siswa mana yang memiliki kelebihan yang menonjol dengan demikian guru tersebut bisa menilai mana siswa yang memiliki motivasi belajar tinggi dan juga mana siswa yang memiliki motivasi belajar rendah. 
Penelitian ini sejalan dengan penelitian yang dilakukan oleh Sumarni (2013) juga menemukan bahwa, pada siswa yang memiliki motivasi tinggi terhadap lingkungan hasil belajar IPA siswa yang mengikuti model pembelajaran TGT lebih tinggi daripada siswa yang mengikuti model pembelajaran konvensional. Berdasarkan penjelasan di atas, jadi pada hipotesi yang ketiga pada siswa yang memiliki motivasi tinggi dan didukung dengan penerapan pendekatan pembelajarn yang tepat, maka motivasi yang tinggi ini secara tidak sadar telah mendorong semangat, keinginan atau kemauan, dan ketekunan siswa untuk belajar. Dengan demikian hasil belajar PKn siswa akan maksimal, karena motivasi belajar yang dimiliki memperkuat tujuan belajarnya. Siswa yang memiliki memiliki motivasi belajar rendah lebih senang mengikuti pembelajaran dengan pendekatan pembelajaran konvensional. Karena siswa terbiasa belajar berorientasi pada penjelasan guru. Trianto (2010) menyatakan bahwa pembelajaran konvensional merupakan pembelajaran yang dimana seluruh kegiatan pembelajaran didominasi oleh guru, guru memberikan adanya yang mendominasi kelompok atau mengantungkan diri pada kelompok. Pola pembelajaran yang terbiasa dilakukan guru (konvensional) terlihat kaku, dimana guru menjelaskan materi sambil menulis di papan tulis dan diseligi dengan tanya jawab, sedangkan siswa memperhatikan penjelasan guru sambil mencatat di buku tulis.Pendapat ini mengemukakan bahwa, siswa dengan motivasi rendah akan dapat diakomodasi dengan pembelajaran yang tepat dan ketepatan mengkombinasikan antara pedekatan pembelajaran dan motivasi berprestasi siswa akan melahirkan hasil yang lebih baik.

Jadi, yang penting dilakukan pada saat pembelajaran pada kelompok siswa dengan motivasi rendah adalah memberikan bimbingan-bimbingan pada setiap langkah pembelajaran, mengemas pembelajaran semenarik mungkin, serta menciptakan suasana yang hangat antara guru dan siswa maupun antar siswa. Dengan demikian, mereka merasa termotivasi untuk menggali lebih jauh informasi mengenai materi yang sedang ia pelajari. Dari paparan di atas tentang model pembelajaran jigsaw I, motivasi belajar serta hasil belajar PKn dapat menjelaskan keterkaitan ketiganya dan sekaligus dapat menjelaskan fenomena dari hasil penelitian ini. Bahwa terdapat hubungan keterkaitan antara hasil belajar PKn dengan model pembelajaran Jigsaw I dan motivasi belajar.

Penelitian ini sejalan dengan penelitian yang dilakukan oleh Puspitasari (2013) menemukan bahwa terdapat perbedaan yang signifikan siswa yang memiliki motivasi belajar rendah antara siswa yang memikuti strategi pembelajaran dengan siswa yang mengikuti pembelajaran konvensional. Data lain yang mendukung ialah penelitian yang dilakukan oleh Sudharmini (2014) juga menemukan bahwa siswa yang memiliki motivasi berprestasi rendah, hasil belajar IPS siswa yang memiliki motivasi rendah yang mengikuti model pembelajaran Jigsaw lebih rendah dari pada hasil belajar PKn siswa yang mengikuti model pembelajaran konvensional. Siswa yang mengikuti model pembelajaran Jigsaw I dengan kondisi rendahnya motivasi belajar yang dimiliki, akan berdampak pada psikologis siswa yaitu mersa terbebani dalam mengikuti pembelajaran.

\section{Simpulan dan Saran}

Dari Berdasarkan hasil perhitungan ANAVA dua jalur diperoleh $\mathrm{F}_{\mathrm{A}}=28,55$, sedangkan $\mathrm{F}_{\text {tabel }}$ dengan $\mathrm{db}_{\text {pembilang }}=1$ dan $\mathrm{db}_{\text {penyebut }}=44$ untuk taraf signifikansi $5 \%=4,08$. Ini berarti, nilai $\mathrm{F}_{\mathrm{A}}$ lebih besar dari pada $F_{\text {tabel }}\left(F_{A}=28,55>F_{\text {tabel }}=4,08\right)$. Ini berarti terdapat perbedaan hasil belajar PKn antara siswa yang mendapat perlakuan model pembelajaran kooperatif tipe Jigsaw I dengan yang mendapat perlakuan pembelajaran konvensional.

Selanjutnya $F_{A B}=7,40$, sedangkan $F_{\text {tabel }}$ dengan $\mathrm{db}_{\text {pembilang }}=1$ dan $\mathrm{db}_{\text {penyebut }}=44$ untuk taraf signifikansi $5 \%=4,08$. Ini berarti, nilai $F_{A B}$ lebih besar dari pada $F_{\text {tabel }}\left(F_{A B}=7,40>F_{\text {tabel }}=4,08\right)$. Oleh karena itu, $\mathrm{H}_{0}$ ditolak dan $\mathrm{H}_{1}$ diterima. Ini berarti bahwa Terdapat pengaruh interaksi yang signifikan antar model pembelajaran Jigsaw I dan motivasi belajar terhadap hasil belajar PKn.

Perhitungan dengan uji t-Scheffe menunjukkan nilai Thitung antara A1B1 dan A2B1 sebesar 5,89, sedangkan $\mathrm{T}_{\text {tabel }}$ pada taraf signifikansi $5 \%$ dengan $\mathrm{k}=4$ dan $\mathrm{dk}=44$ maka diperoleh $\mathrm{T}_{\text {tabel }}=3,79$. Hasil tersebut menunjukkan nilai $\mathrm{T}_{\text {hitung }}$ lebih besar daripada $\mathrm{Q}_{\text {tabel }}$ sehingga $\mathrm{H}_{0}$ ditolak dan $\mathrm{H}_{1}$ diterima. Hal itu berarti untuk kelompok siswa yang memiliki motivasi tinggi, terdapat perbedaan yang signifikan hasil belajar PKn antara siswa yang mendapat perlakuan model pembelajaran kooperatif tipe Jigsaw I dengan yang mendapat perlakuan pembelajaran konvensional.

Perhitungan dengan uji t-Scheffe menunjukkan nilai $\mathrm{T}_{\text {hitung }}$ antara A1B2 dan A2B2 sebesar 5,46, sedangkan $\mathrm{T}_{\text {tabel }}$ pada taraf signifikansi $5 \%$ dengan $\mathrm{k}=4$ dan $\mathrm{dk}=44$ maka diperoleh $\mathrm{T}_{\text {tabel }}=3,79$. Hasil tersebut menunjukkan nilai $\mathrm{T}_{\text {hitung }}$ lebih besar daripada $\mathrm{T}_{\text {tabel }}$ sehingga $\mathrm{H}_{0}$ ditolak dan $\mathrm{H}_{1}$ diterima. Hal itu berarti untuk kelompok siswa yang memiliki motivasi rendah, terdapat perbedaan yang signifikan hasil belajar PKn antara siswa yang mendapat perlakuan model pembelajaran kooperatif tipe Jigsaw I dengan yang mendapat perlakuan pembelajaran konvensional. 
Saran yang dapat disampaikan berdasarkan penelitian yang telah dilakukan adalah sebagai berikut. (1) Bagi guru lebih berinovasi dalam menggunakan model pembelajaran agar dapat mencapai tujuan pembelajaran yang sesuai dengan karakteristik mata pelajaran tersebut, khususnya pada mata pelajaran PKn. Salah satunya adalah dengan menerapkan model pembelajaran Kooperatif Tipe Jigsaw I untuk meningkatkan hasil belajar PKn siswa. Karena dengan mengkondisikan model Pembelajaran ini akan mampu meningkatkan motivasi belajar siswa dan memantau, membimbing, memfasilitasi, dan memotivasi siswa dalam proses pembelajaran. Hal ini diperlukan agar guru dapat membantu siswa menjadi lebih aktif, keratif, dan efektif untuk mencapai tujuan pembelajaran. (2) Bagi peneliti lain, Hasil penelitian ini diharapkan dapat menjadi informasi berharga bagi para peneliti bidang pendidikan, untuk meneliti aspek atau variabel lain yang diduga memiliki kontribusi terhadap konsep-konsep dan teori-teori tentang pembelajaran khususnya mata pelajaran PKn.

\section{Daftar Rujukan}

B.Uno, H. (2016). Teori Motivasi dan Pengukurannya Analisis di Bidang Pendidikan. Jakarta: Bumi Aksara.

Dantes, N. (2012). Metode Penelitian. Yogyakarta: CV ANDI OFFSET.

Djudin, T. (2016). Pengaruh Model Pembelajaran Kooperatif Tipe Jigsaw Terhadap Hasil Belajar Siswa Pada Materi Vektor Di Kelas X Sma Negeri 1 Sanggau Ledo. . Jurnal Penelitian Fisika Dan Aplikasinya (JPFA), 6(2).

Hyani. (2013). Determinasi Minat Belajar, Motivasi Berprestasi, dan Gaya Belajar terhadap Hasil Belajar IPS MIN Yeh Sumbul Kecamatan Mendoyo Kabupaten Jembrana. Universitas Pendidikan Ganesha.

Ismiyatun. (2014). Penerapan Model Pembelajaran Kooperatif Tipe Jigsaw Untuk Meningkatkan Hasil Belajar Siswa Pada Mata Pelajaran IPA di Kelas IV SD Inpres 2 Ambesia Kecamatan Tomini. Jurnal Kreatif Tadulako Online, 4(6), 119-132.

Koyan, I. W. (2012). Statistika Terapan ( Teknik Analisis Data Kuantitatif). Singaraja: Universitas Pendidikan Ganesha.

Murda, I. N. (2013). Kontribusi Minat Belajar, Minat Belajar, Motivasi Berprestasi dan Gaya Belajar terhadap Hasil Belajar Konsep Dasar IPS Mahasiswa S1 PGSD FIP Undiksha. Universitas Pendidikan Ganesha.

Puspitasari, N. L. P. E. (2013). Pengeruh Strategi Pembelajaran PQ4R dan Motivasi Belajar Terhadap Hasil Belajar PKn Siswa Kelas IV SD Gugus 2 Tampaksiring. E-Journal PGSD Pendidikan Ganesha Mimbar $P G S D, 1(1)$.

Rosyindah, U. (2016). Pengaruh Model Pembelajaran Kooperatif Tipe Jigsaw Terhadap Hasil Belajar Matematika Siswa Kelas Viii Smp Negeri 6 Metro. Jurnal SAP UNINDRA, 1(2), 115-124.

Rusman. (2010). Model-model Pembelajaran (Mengembangkan Profesionalisme Guru Edisi Kedua). Jakarta: Raja Grafindo Persada.

Rusman. (2016). Model-model Pembelajaran Mengembangkan Profesionalisme Guru. Bandung: PT Mulia Mandiri Press.

Sudharmini, L. . (2014). Pengaruh Model Pembelajaran Kooperatif Tipe Jigsaw terhadap Motivasi Belajar dan Hasil belajar IPS Siswa Kelas V Sekolah Dasar Gugus IV Jimbaran, Kuta. Journal Program Pascasarjana Universitas Pendidikan Ganesha Program Studi Pendidikan Dasar, 4(1).

Sumarni, N. . (2013). Pengaruh Model Pembelajaran Kooperatif Tipe Terhadap Hasil Belajar IPA ditinjau dari Motivasi Berprestasi terhadap Lingkungan pada Siswa Kekas V SD se-Gugus Subangkaja. Univeritas Pendidikan Ganesha.

Suparman. (2014). Penerapan Model Pembelajaran Kooperatif Tipe Jigsaw Untuk Meningkatkan Aktivitas Dan Hasil Belajar Ipa Pada Konsep Pencemaran Lingkungan. Jurnal SSIOêduKASI, 3(1), 293-298.

Suprihatin, S. (2017). Penggaruh Model Pembelajaran Jigsaw Terhadap Hasil Belajar Studi Masyarakat Indonesia Mahasiswa. Jurnal Pendidikan Ekonomi UM Metro, 5(1), 84-94.

Suprijono, A. (2009). Cooperative Learning : Teori dan Aplikasi PAIKEM. Yogyakarta: Pustaka Pelajar.

Susanto, A. (2013). Teori Belajar dan Pembelajaran di Sekolah Dasar. Jakarta: Kencana Predana Media 
Group.

Trianto. (2010). Mendesain Model Pembelajaran Inovatif-Progresif. Jakarta: Kencana. 